\title{
PEMBELAJARAN MENULIS ARTIKEL BERBASIS STRATEGI THINK-TALK-WRITE UNTUK MAHASISWA PBSI UMUS
}

\author{
Agnes Apryliana, M.Pd \\ Program Studi Pendidikan Bahasa dan Sastra Indonesia, Universitas Muhadi Setiabudi \\ Brebes \\ Jln. Pangeran Diponegoro KM 2 Wanasari Brebes, Jawa Tengah, 52221 Indonesia. \\ *Koresponden Penulis, Email Agnes andini@yahoo.com. Telepon: 085227895764
}

\begin{abstract}
Abstrak
Pembelajaran menulis karangan eksposisi berbasis strategi Think-Talk-Write merupakan kegiatan pembelajaran aktif yang melibatkan siswa dan guru sebagai pelaku pembelajaran. Kemampuan menulis menjadi salah satu pembelajaran yang penting untuk dipelajari oleh mahasiswa. Menerapkan strategi TTW dalam pembelajaran menulis menjadi salah satu solusi bagi pengajar saat kegiatan pembelajran dimulai. Penelitian ini bertujuan untuk (1) menguji keefektifan strategi Think-Talk-Write dalam pembelajaran menulis artikel ilmiah pada mahasiswa PBSI UMUS.Penelitian ini merupakan jenis penelitian eksperimen kuasi dengan membandingkan dua strategi dalam pembelajaran, yaitu strategi tradisional dan strategi TTW. Subjek uji coba adalah mahasiswa PBSI UMUS semester 6 tahun ajaran 2017/2018 yang diambil secara random. Prosedur penelitian memiliki tiga tahap, yaitu (1) tahap ujicoba instrumen penilaian dan uji normalitas, (2) tahap pembelajaran, (3) tahap uji akhir.
\end{abstract}

Kata Kunci: strategi think-talk-write, menulis artikel ilmiah, karangan ilmiah.

\section{Abstract}

\section{Learning to Write Articels Based on Think-Talk-Write Strategy for Student in PBSI UMUS}

Learning to write exposition essays based on Think-Talk-Write strategy is an active learning activity that involves students and teachers as learning participants. Writing ability is one of the important lessons to be learned by students. Implementing the TTW strategy in writing learning is one of the solutions for teachers when learning activities begin. This study aims to (1) examine the effectiveness of Think-Talk-Write strategies in learning to write scientific articles on UMSI PBSI students.This research is a type of quasi experimental research by comparing two strategies in learning, namely traditional strategies and TTW strategies. The trial subjects were students of the 6th semester PBSI UMUS 2017/2018 academic year who were taken randomly. The research procedure has three stages, namely (1) the stage of testing the assessment instrument and the normality test, (2) the learning stage, (3) the final test stage. Data collection uses test techniques in written form.

Kata Kunci: think-talk-write strategy, writing aericels, write 


\section{PENDAHULUAN}

Menulis merupakan kegiatan yang berkaitan dengan kreativitas dalam mengungkap ide, gagasan, dan pendapat. Hasil dari tulisan diharapkan mampu memberikan sumbangsih untuk menyelesaikan berbagai permasalahan yang timbul di masyarakat. Kegiatan menulis menjadi penting untuk mendukung kreativitas dan eksistensi seseorang dalam bidang ilmu yang dimilikinya. Menulis pada hakikatnya adalah menuangkan buah pikiran atau gagasan ke dalam sebuah media tulis melalui kalimat yang dirangkai secara utuh, lengkap, jelas, dan mampu merepresentasikan hal-hal yang dimaksud dalam pikiran, sehingga buah pikiran tersebut mampu dikomunikasikan kepada pembaca dengan jelas (Brown, 2001). Menulis merupakan media komunikasi yang dapat menghubungkan ruang dan waktu. Oleh karena itu, kegiatan menulis menjadi kursial dalam kehidupan manusia. Manusia tidak dapat terlepas dari kegiatan tulis menulis.

Dalam kegiatan pembelajaran di sekolah ataupun kampus terutama pada mata kuliah penulisan artikel ilmiah menjadi salah satu kemampuan yang harus dikuasai oleh peserta didik. Kemampuan menulis siswa akan terlihat dari hasil tulisan mereka yang tidak terlepas dari bimbingan guru. Menulis menjadi satu kompetensi dasar yang harus diajarkan sejak usia dini. Menulis pada dasarnya merupakan kemampuan tertinggi di antara kemampuan berbahasa lainnya yang harus dikuasai oleh siswa. Senada dengan pendapat Burhan Nurgiyantoro (2012) yang menyatakan keterampilan menulis merupakan keterampilan paling akhir dikuasai oleh pelajar bahasa setelah kemampuan mendengarkan, berbicara, dan membaca.

Mertens (2010) berpendapat bahwa menulisadalah kegiatan yang kompleks danmenuntut kognitif. Agar menjadi sukses dalam pembelajaran menulissiswa memerlukanpemahaman tentang berbagai komponen pendukung mengenai pengetahuan tahapan-tahapan menulisyang dapat digunakanuntuk membantu, mengatur,dan mengarahkan siswa dalamproses penulisan. Kegiatan menulis menjadi penting untuk dipelajari dan dikembangkan, terutama dalam bidang keilmuan yang dimiliki oleh seseorang. Pembelajaran menulis di sekolah menjadi penting untuk diajarkan kepada para siswa. Meskipun pembelajaran tulis menulis telah dipelajari kenyataannya kemampuan menulis siswa Indonesia masih belum mampu menyaingi kemampuan menulis siswa dari negara lain, contohnya seperti para siswa dari Malaysia atau negara lain di kawasan Asia Tenggara.

Bahasa sebagai wahana untuk mengekspresikan perasaan dan pemikiran secara estetis dan logis. Pada satu saat, bahasa tidak dituntut dapat mengekspresikan sesuatu dengan efisien karena ingin menyampaikannya dengan indah sehingga mampu menggugah perasaan penerimanya. Pada saat yang lain, penggunaan bahasa hendaknya efisien dalam menyampaikan gagasan secara objektif dan logis supaya dapat dicerna dengan mudah oleh penerimanya. Dua strategi mengekspresikan dua dimensi diri, perasaan dan pemikiran, melalui bahasa perlu dilakukan secara berimbang.

Sejalan dengan peran itu, pembelajaran menulis karangan ilmiah menempatkan Bahasa Indonesia sebagai wahana untuk mengekspresikan ide, gagasan, dan pemikiran. Didalamnya dijelaskan berbagai cara penyajian pikiran dalam berbagai macam jenis teks. Pemahaman terhadap jenis, kaidah, dan konteks suatu teks ditekankan sehingga 
memudahkan peserta didik menangkap makna yang terkandung dalam suatu teks. Penyajian perasaan dan pemikiran dalam bentuk teks yang sesuai agar tujuan penyampaiannya tercapai, apakah untuk menggugah perasaan ataukah untuk memberikan pemahaman perlu dilakukan secara terstruktur. Bahasa Indonesia diajarkan bukan sekadar sebagai pengetahuan bahasa, melainkan sebagai teks yang mengemban fungsi untuk menjadi sumber aktualisasi diri penggunanya pada konteks sosial-budaya akademis. Teks merupakan satuan bahasa yang berisi ungkapan makna secara kontekstual.

Dalam kehidupan sehari-hari, manusia tidak dapat terlepas dari penggunaan teks yang berupa lisan, tulisan, atau multimodal seperti gambar. Sebagai contoh, orang untuk mengurus SIM, KTP, paspor, atau surat-surat penting yang lain untuk berobat di rumah sakit, dan untuk menjalani kegiatan lain yang membutuhkan langkah-langkah tertentu. Orang menggunakan teks dalam bentuk karya ilmiah dengan tujuan untuk menjabarkan berbagai keilmuan terbaru untuk memberikan perhatian lebih pada hal-hal yang belum pernah ditemukan atau diamati oleh manusia pda umumnya. Jenis karangan ilmiah tersebut diproduksi dalam konteks sosial yang melatarbelakangi kegiatan-kegiatan yang dilakukan oleh manusia, baik konteks situasi maupun konteks budaya. Dalam membuat sebuah teks memerlukan adanya pengaruh eksteren yang menjadi latar belakang seseorang untuk membuat sebuah teks. Dalam sebuah pembelajaran menulis teks atau karangan lingkungan peserta didik dapat mempengaruhi hasil tulisan. Misalnya saja, suatu lingkungan kelas yang sunyi akan memberikan efek berbeda pada hasil tulisan. Oleh karena itu, penting bagi guru untuk memberikan stimulan kepada peserta didik sebelum memberikan tugas menulis karangan atau teks.

Menciptakan pembelajaran yang menyenangkan dapat dilakukan dengan menggunakan strategi yang disesuaikan dengan kondisi peserta didik. Pemilihn strategi yang tepat dan disesuikan dengan kondisi peserta didik akan memberikan hasil yang maksimal dari proses pembelajaran. Guru perlu memberikan perhatian yang lebih terhadap pemilihan strategi pembelajaran. Tidak hanya strategi pembelajaran yang perlu untuk guru perhaikan dalam sebuah proses pembelajaran dengan tujuan untuk menciptakan hasil yang maksimal. Bahan ajar juga memerlukan perhatian dari guru. Bahan ajar yang telah disesuaikan dengan strategi pembelajaran dapat mempengaruhi proses kegiatan belajar. Bahan ajar sangat perlu bagi guru sebagai sumber ilmu. Seorang pengajar memerlukan berbagai macam bahan ajar yang disesuaikan dengan kebutuhan materi dan kondisi peserta didik.

Terdapat banyak strategi pembelajaran yang telah diciptakan oleh para ahli dibidang pendidikan. Salah satu strategi pembelajaran, yaitu strategi TTW (Think-Talk-Write). Think-Talk-Write yang selanjutnya dalam penelitian ini akan ditulis dengan TTW. TTW merupakan strateggi pembelajaran yang menitikberatkn pada kegiatan berpikir, berbicara (berdiskusi), dan menulis. Strategi ini memungkinkan siswa untuk menggali informasi lebih dalam melalui kegiatan berpikir dan berdiskusi yang selanjutnya menulis.

Berdasarkan penjelasan mengenai pentingnya sebuah strategi pembelajaran dan bahan ajar sebagai pendukung oleh karena itu, penelitian ini akan memfokuskan pada penelitian implementasi strategi Think-Talk-Write dalam pembelajaran menulis artikel ilmiah untuk mahasiswa PBSI UMUS semester 6 tahun 2017/2018. Tujuan dari kegiatan ini adalah untuk mengetahui keefektifan pada implementasi strategi Think-Talk-Write 
dalam pembelajaran menulis artikel ilmiah untuk mahasiswa PBSI UMUS semester 6 tahun 2017/2018.

\section{KAJIAN TEORI}

\section{A. Keterampilan Menullis}

Menulis pada hakikatnya adalah menuangkan buah pikiran atau gagasan ke dalam sebuah media tulis melalui kalimatkalimat yang dirangkai secara utuh, lengkap, jelas, dan mampu merepresentasikan hal-hal yang dimaksud oleh pikiran, sehingga buah pikiran tersebut mampu dikomunikasikan kepada pembaca dengan jelas (Brown, 2001). Menulis menjadi media komunikasi yang dapat menghubungkan ruang dan waktu. Kegiatan menulis menjadi kursial dalam kehidupan manusia. Manusia dalam kegiatan sehari-hari tidak dapat terlepas dari kegiatan tulis menulis. Menulis tidak lagi dilihat sebagai cara untuk merekam pikiran, perasaan, dan ide-ide, tetapi juga sebagai sarana utama menghasilkan dan mengeksplorasi pikiran dan ide-ide baru (Kern, 2014).

Menulis adalah kegiatan komunikasi antara penulis dan pembaca, sebuah rencana, hasil dari pemikiran, imajinasi, mengingat, mengkoleksi seluruh data informasi, tulisan menyatukan ruang dan waktu (Moore-Hart, 2010). Abidin (2012) berpendapat bahwa menulis adalah sebuah proses berkomunikasi secara tidak langsung antara penulis dan pembaca. Sebuah tulisan dibuat untuk dipahami maksud dan tujuannya sehingga proses yang dilakukan tidaklah sia-sia. Dalam sudut pandang lain menulis dapat pula dikatakan sebagai kegiatan mereaksi, artinya menulis adalah proses mengemukakan pendapat atas dasar masukan yang diperoleh penulis dari berbagai sumber gagasan yang tersedia.

Keterampilan menulis telah dianggap sebagai keterampilan yang paling sulit untuk diajarkan dan diperoleh karena menulis adalah aktivitas kognitif paling kompleks yang mewajibkan peserta didik untuk memperhatikan konten, struktur kalimat, kosakata, tanda baca, dan ejaan secara bersama-sama (Mourssi, 2013). Bayat (2014) menjelaskan bahwa ekspresi tertulis adalah keterampilan berbahasa yang sulit bagi siswa. Hyland (2004) menjelaskan bahwa menulis merupakan kemampuan yang sangat penting untuk dimiliki oleh setiap orang. Oleh karena itu, guru sangat perlu menyampaikan materi atau pengetahuan tentang menulis kepada para siswanya.Menulis bukan hanya sekedar untuk komunikasi tetapi juga sebagai penyelesaian tugas yang bermakna dalam pembelajaran, pemikiran, dan mengorganisir pengetahuan atau gagasan. Dengan kata lain, menulis adalah suatu aktivitas kompleks yang menyertakan beberapa langkah-langkah (Widodo, 2008).

Nunan (2003) menjelaskan kegiatan menulis dapat didefinisikan sebagai berikut: (1) kegiatan menulis adalah suatu kegiatan yang berupa fisik dan tindakan mental. Pada tingkat yang paling dasar menulis adalah tindakan fisik menuangkan kata-kata atau ide untuk beberapa media, menulis adalah pekerjaan mental yang menciptakan ide-ide, berpikir tentang bagaimana mengekspresikan kata-kata, dan mengorganisir kosakata ke dalam laporan atau dalam bentuk paragraf yang akan jelas bagi pembaca, (2) tujuan menulis adalah untuk mengekspresikan dan terkesan. Penulis memiliki posisi sebagai tuan yang mengekspresikan keseluruhan gagasan yang dimilikinya, sedangkan pembaca diposisikan sebagai penonton atau penerima informasi yang sedang disampaikan penulis dalam bentuk tulisan, (3) kegiatan menulis merupakan sebuah proses dan produk. Penulis membayangkan, mengatur, membuat draft, mengedit, membaca dan membaca ulang. Proses penulisan sering berubah dan kadang-kadang tidak teratur. Oleh karena itu, kegiatan menulis membutuhkan sebuah proses yang dilakukan sesuai 
dengan tahapan-tahapan.

Berdasarkan penjelasan di atas dapat disimpulkan bahwa kegiatan menulis tidak hanya membutuhkan langkah atau tahapan saja, namun juga memerlukan tujuan. Setiap jenis teks memiliki tujuannya masing-masing, sebuah tulisan harus mengandung tujuan yang jelas, dan informasi yang ingin disampaikan penulis harus dikemas dalam bentuk yang efektif. Melalui sejumlah elemen teks yang perlu disusun secara urut dan dituangkan dalam sejumlah kalimat dengan menggunakan tata bahasa yang tepat. Kegiatan tulis menulis menjadi sangat kursial untuk dipelajari.

Karangan ilmiah atau artikelilmiah merupakan tulisan yang ilmiah dapat berbentuk artikel ulasan (review articel) maupun artikel penelitian (research articel) dari laporan hasil penelitian yang ditulis kemali oleh para penulisya untuk dipublikasikan dalam jurnal ilmiah (Abdullah dalam Alfiyanti, 2015: 24).

Karangan ilmiah memiliki beberapa karakeristik, yaitu (1) mengacu pada teori, (2) berdasarkan fakta yang ada, (3) logis, (4) Objektif, (5) sistematis, (6) data valid dan jelas, (7) pembahasan yang detail dan tuntas, (8) disusun dalam bahasa yang baku.

\section{B. Strategi Think-Talk-Write}

\section{Strategi Think-Talk-Write (TTW)}

Strategi TTW yang diperkenalkan oleh Huinker \& Laughlin ini pada dasarnya dibangun melalui berpikir, berbicara, dan menulis. Strategi TTW adalah sebuah pembelajaran yang dimulai dengan berpikir melalui bahan bacaan (menyimak, mengkritisi, dan solusi alternatif), hasil bacaan dikomunikasikan dengan presentasi, diskusi, kemudian membuat laporan hasil presentasi (Huinker via Yamin, 2009: 84). Strategi TTW mendorong siswa untuk berpikir berbicara, dan kemudian menuliskan suatu topik tertentu (Huda, 2015: 218). Strategi TTW mendorong siswa unuk berpikir, berbicara, dan kemudian menulis. Strategi TTW memperkenankan siswa untuk memengaruhi dan memanipulasi ide-ide sebelum menuangkanya dalam bentuk tulisan. Strategi TTW juga membantu siswa dalam mengumpulkan dan mengembangkan ide-ide melalui percakapan struktur. Langkah-Langkah PenerapaNStrategi Think-Talk-Write (TTW)

Strategi TTW memiliki sintak yang sesuai dengan urutannya yaitu berpikir (think), berbicara (talk), dan menulis (write). Berikut ini tahapn yang diperlukan untuk menerapkan srategi TTW dalam pembelajaran menulis (Huda, 2015: 218220).

a. Tahap 1: Think (Berpikir)

Siswa membaca teks berupa soal memungkinkan (kalau memungkinkan dimulai dengan soal yang berhubungan dengan permasalahan sehari-hari atau kontekstual). Pada tahap ini siswa secara individu memikirkan kemungkinan jawaban (strategi penyelesaian), membuat catatan kecil tentang ide-ide yang terdapat pada bacaan, dan hal-hal yang idak dipahami dengan menggunakan bahasanya sendiri.

b. Tahap 2: Talk (Berbicara/Berdiskusi)

Siswa diberi kesempatan untuk membicarakan hasil penyelidikannya pada tahap pertama. Pada tahap ini siswa merefleksikan, menyusu, serta menguji (negosiasi sharing) ide-ide dalam kegiatan diskusi kelompok. Kemajuan komunikasi siswa akan terlihat pada dialognya dalam diskusi, baik dalam bertukr ide dengan orang lain ataupun refleksi mereka sendiri yang diungkapkannya kepada orang lain.

c. Tahap 3: Write (Menulis)

Pada tahap ini, siswa menuliskan ideide yang diperolehnya dan kegiatan tahap pertama dan kedua. Tulisan ini terdiri atas landasan konsep yang digunakan, 
keterkaitan dengan materi sebelumnya, strategi penyelesaiannya, dan solusi yang diperoleh.

Silver dan Smith (via Huda, 2015) menjelaskan bahwa peranan dan tugas guru dalam usaha mengefektifkan penggunaan strategi TTW adalah mengajukan dan menyediakan tugas yang memungkinkan siswa terlibat secara lisan dan tulisan dengan hati-hati, mempertimbangkan dan memberi informasi terhadap apa yang digali siswa dalam diskusi, serta memonitor, menilai, dan mendorong siswa untuk berpartisipasi secara aktif. Tugas yang disiapkan diharapkan dapat menjadi pemicu siswa untuk bekerja secara aktif, seperti soal- soalyang memiliki jawaban divergen atau open-ended task.

Untuk mewujudkan pembelajaran yang sesuai dengan harapan di atas, pembelajaran sebaiknya dirancang sesuai dengan langkah-langkah berikut ini:

1) Siswa membaca teks dan membuat catatan dari hasil bacaan secara individual (think), untuk dibawa ke forum diskusi.

2) Siswa berinteraksi dan berkolaborasi dengan teman satu grup untuk membahas isi catatan. Dalam kegiatan ini mereka menggunakan bahasa dan kata-kata mereka sendiri untuk menyampaikan ide-ide dalam diskusi. Pemahaman dibangun melalui interaksi dalam diskusi, karena itu diskusi diharapkan dapat menghasilkan solusi atas soal yang diberikan.

3) Siswa mengonstruksi sendiri pengetahuan yang memuat pemahaman dan komunikasi dalam bentuk tulisan. Kegiatan terakhir pembelajaran adalah membuat refleksi dan kesimpulan atas materi yang dipelajari. Sebelum itu, dipilih satu atau beberapa orang siswa sebagai perwakilan kelompok untuk menyajikan jawaban, dan kelompok lain diminta memberikan tanggapan.
Dalam penelitian ini menerapkan jenis penelitian eksperimen kuasi yang menggunakan dua kelas dan terbagi menjadi kelas eksperimen dan kelas kontrol. Dua kelas tersebut mendapatkan perlakuan yang sama banyak dalam pembelajaran menulis artikel ilmiah. Kelas eksperimen menerapkan strategi TTW, sedangkan kelas kontrol menggunakan pembelajaran menulis artikel ilmiah dengan menerapkan strategi konvensional. Teknik pengumpulan data yang digunakan adalah dalam bentuk tes menulis artikel ilmiah. Validitas instrumen dalam bentuk tes menulis artikel ilmiah Uji keefektifan yang digunakan adalah uji-t atau uji beda.

\section{METODE PENELITIAN}

Jenis penelitian adalah eksperimen semu. Jenis penelitian eksperimen semu dipilih karena tidak membuat kelompok baru, tetapi menggunakan kelas-kelas sebagaimana adanya. Melibatkan dua variabel yaitu variabel bebas dan variabel terikat. Variabel bebas dalam penelitian adalah strategi pembelajaran yang akan diuji cobakan dan terdiri atas dua strategi, yakni strategi TTW (X1) dan strategi konvensional (X2), dan variabel terikat adalah kemampuan menulis karangan karya ilmiah mahasiswa PBSI semester 6 tahun ajaran 2017/2018.

Desain ekperimental yang digunakan adalah rendomized pre-tes-posttest control group design. Terdapat dua kelompok dalam penelitian ini, yaitu satu kelompok eksperimen dan satu kelompok kontrol, kemudian masing-masing kelompok diberi prates dan pascates. Penelitian dilakukan pada mahasiswa PBSI UMUS semester 6 tahun ajaranan 2017/2018. Waktu penelitian dilakukan pada bulan Maret tahun pelajaran 2017/2018.

Populasi penelitian adalah seluruh mahasiswa semester 6 tahun ajaran 2017/2018. Teknik pengambilan sampel 
yang digunakan adalah teknik sampel acak berlapis. Teknik sampel acak berlapis (multistage random sampling) adalah teknik pengambilan sampel yang merupakan pengembangan dari teknik acak klaster (Eriyanto, 2007).

Instrumen yang digunakan dalam penelitian adalah soal menulis dan lembar penilaian karya ilmiah. Lembar penilaian digunakan untuk menilai hasil karya ilmiah peserta didik. Penyusunan instrumen penelitian mengacu pada kisikisi lembar penilaian.

Pengujian kadar validitas instrumen menggunakan uji validitas isi yang terdapat pada lembar penilaian menulis karangan argumentasi. Uji validitas isi menggunakan peran ahli untuk memberikan koreksi dan penilaian terhadap instrumen. Ahli yang diminta untuk memberikan pendapat dan koreksinya adalah Dr. Teguh Setiawan, M.Hum. Selanjutnya, instrumen yang dinyatakan valid didiskusikan bersama guru.

Reliabilitas instrumen diuji menggunakan teknik Alpha Cronbach. Skor yang terdapat pada lembar penilaian berupa skala dengan jumlah skor tertinggi, yaitu 100. Sebuah instrumen dikatan reliabel jika harga $r$ yang diperoleh paling tidak mencapai 0,60 (Nurgiyantoro, 2012).

Berdasarkan hasil uji reliabilitas terhadap instrumen penelitian menghasilkan skor yang lebih tinggi dari

harga kritik indeks dan skor SEM yang dihasilkan sebesar 3,122. Dari kedua skor tersebut dapat disimpulkan bahwa instrumen yang telah diujicobakan memiliki tingkan reliabilitas yang tinggi. Instrumen tersebut dapat digunakan dalam penelitian ini.

Asumsi yang harus dipenuhi dalam uji-t dan Anava satu jalur yaitu: (1) populasi yang diuji memiliki distribusi normal, (2) varian/ragam dari populasi yang sama, dan (3) sampel tidak berhubungan satu dengan yang lain (Badri, 2012). Teknik analisis data yang digunakan adalah uji-t sampel bebas.. Asumsi untuk uji-t sampel bebas sebagai berikut: (1) jika skor $t_{\text {hitung }}$ baik dihitung dengan varian yang sama atau berbeda menghasilkan skor lebih besar dari $t_{\text {tabel }}$ dan taraf signifikasi yang sama-sama signifikan, yaitu kurang dari 0,05, hipotesis kerja diterima, (2) jika skor $t_{\text {hitung }}$ baik dihitung dengan varian yang sama atau berbeda menghasilkan skor lebih kecil dari $t_{\text {tabel }}$ dan menghasilkan taraf signifikasi lebih besar dari 0,05,hipotesis kerja ditolak.

\section{HASIL DAN PEMBAHASAN}

\section{A. Deskripsi Data Penelitian}

Kelompok 1 sebagai kelas eksperimen menggunakan strategi TTW, dan kelompok 2 sebagai kelas kontrol menggunakan strategi konvensional dalam pembelajaran menulis artikel ilmiah. Sebelum melakukan analisis data, langkah pertama yang dilakukan, yakni uji prasyarat analisis, yaitu dengan menguji data prates guna mencari normalitas dan homogenitas.

Data berupa nilai dari hasil kemampuan menulis artikel ilmiah peserta didik. Penilaian terhadap kemampuan membaca sastra dilaksanakan dua kali, yaitu sebelum dan sesudah pelaksanaan pembelajaran. Pelaksanaan prates dilakukan sesuai dengan jadwal pelajaran di kelas. Rangkuman hasil prates kelompok eksperimen dan kelompok kontrol terdapat dalam Tabel 1.

Tabel 1. Rangkuman Data Hasil

PratesKemampuan Membaca Sastra

\begin{tabular}{|c|c|c|}
\hline & $\begin{array}{c}\text { Kelas } \\
\text { Eksperimen 1 }\end{array}$ & $\begin{array}{c}\text { Kelas } \\
\text { Kontrol }\end{array}$ \\
\hline $\mathbf{N}$ & $\underline{20}$ & $\underline{20}$ \\
\hline Mean & 67,30 & 63,75 \\
\hline Std. Dev & 1,302 & 1,803 \\
\hline Minimun & 65 & 61 \\
\hline Maximum & 70 & 67 \\
\hline
\end{tabular}


Uji normalitas

$$
\text { dilakukan berdasarkan }
$$

data prates yang dihasilklan oleh kelompok eksperimen dan kelompok kontrol. Dilakukan dengan tujuan untuk mengetahui sebaran data, apakah berdistibusi normal atau tidak. Uji normalitas yang dilakukan terhadap skor menulis karangan argumentasi berupa data prates yang dilakukan menggunakan uji kolmogorov-smirnov dengan taraf signifikan $(\alpha=0,05)$. Menguji normalitas suatu data dapat dilakukan dengan melihat kaidah signifikasi $(p)$. Asumsi uji normalitas, yaitu jika skor $(p)$ $\geq 0,05$, maka data berdistribusi normal. Jika skor

(p) $\leq 0,05$, maka data tidak berdistribusi normal. Berdasarkan hasil uji asumsi normalitas data prates menunjukkan bahwa sampel yang digunakan dalam penelitian ini berdistribusi normal, yaitu $p \geq 0,05$. Kelompok eksperimen 1 memperoleh skor $p$ sebesar 0,694, dan kelompok kontrol memeroleh skor $p$ sebesar 0,771. Tahap selanjutnya adalah melakukan uji homogenitas data prates. Berikut ini tabel hasil uji normalitas data prates

\begin{tabular}{|c|c|c|}
\hline Kelompok & $\begin{array}{l}\text { Kolmogorov- } \\
\text { Smirnov }\end{array}$ & $\begin{array}{l}\text { Asymp. } \\
\text { Sig. (2- } \\
\text { tailed) }\end{array}$ \\
\hline Eksperimen 1 & 0,710 & 0,694 \\
\hline $\begin{array}{l}\text { Kontrol } \\
\text { (Konvensional) }\end{array}$ & 0,663 & 0,771 \\
\hline
\end{tabular}

Uji homogentitas memiliki ketentuan bahwa semua data atau kelompok yang digunakan dalam penelitian haruslah dalam keadaan yang homogen. Uji homogentas dilakukan dengan menggunakan program SPSS versi 21.00 yang memperhatikan skor pada bagian Lavene statistic. Untuk mengetahui data tersebut homogen atau tidak dapat dilihat dari skor signifikasi $(p)$ yang didapatkan. Asumsi uji homogenitas data prates, yaitu jika $p \geq 0,05$ maka data tersebut bersifat homogen atau sama, dan jika skor $p \leq 0,05$ maka data tersebut bersifat heterogen. Dari hasil statistik levene diperoleh sig sebesar 0,082 , skor tersebut menunjukkan bahwa skor $p \geq 0,05$. Dapat disimpulkan pada taraf signifikasi 0,05 , semua kelompok yang digunakan dalam penelitian memiliki variasi kelompok yang sama.

Selanjutnya, dilakukan tahap perlakuan. Pada tahap perlakuan penelitian dilaksanakan selama 4 kali pertemuan pada masing-masing kelas. Setelah melakukan prates dan perlakuan pada masing-masing kelas penelitian, tahap terakhir adalah melakukan tes akhir guna mengetahui keefektifan strategi TTW dan strategi konvensional. Langkah selanjutnya adalah membandingkan tingkat keefektifan pada kedua strategi yang digunakan dalam penelitian. Skor Prates dan Skor Pascates Kemampuan Menulis Artikel Ilmiah Kelompok Eksperimen

Pada pertemuan pertama dilakukan uji kemampuan awal dengan tujuan untuk mengetahui kemampuan awal peserta didik dalam kemampuan menulis artikel ilmiah. Berikut ini perbandingan hasil uji praeksperimen kelas kontrol dan kelas eksperimen.

Tabel 3. Perbandingan Hasil Prates

\begin{tabular}{|c|c|c|}
\hline & $\begin{array}{c}\text { Kelas } \\
\text { eksperimen }\end{array}$ & $\begin{array}{c}\text { Kelas } \\
\text { Kontrol }\end{array}$ \\
\hline $\mathrm{N}$ & \multirow[t]{2}{*}{20} & 20 \\
\hline Valid & & \\
\hline & \multirow[t]{2}{*}{0} & 0 \\
\hline Missing & & \\
\hline Mean & 67,30 & $\underline{63,75}$ \\
\hline Std. Deviation & 1,302 & $\overline{1,803}$ \\
\hline Variance & 1,695 & $\overline{3,250}$ \\
\hline Minimum & 65 & $\underline{61}$ \\
\hline Maximum & 70 & $\underline{67}$ \\
\hline
\end{tabular}

Pertemuan selanjutnya dilakukan perlakuan atau proses pembelajaran menulis artikel ilmiah dengan menggunakan strategi TTW dan strategi konvensional. Pertemuan terakhir 
dilakukan uji akhir, yaitu melakukan tes keterampilan menulis artikel ilmiah. Berikut ini hasil uji akhir dari kelompk eksperimen dan kelompok kontrol.

Tabel 4. Perbandingan Hasil Uji Pasca

tes

\begin{tabular}{|c|c|c|}
\hline & $\begin{array}{c}\begin{array}{c}\text { Kelas } \\
\text { eksperimen }\end{array} \\
\end{array}$ & $\begin{array}{c}\text { Kelas } \\
\text { Kontrol }\end{array}$ \\
\hline $\begin{array}{l}\mathrm{N} \\
\text { Valid }\end{array}$ & 20 & 20 \\
\hline Missing & 0 & 0 \\
\hline Mean & 72,35 & 64,80 \\
\hline Std. Deviation & 2,159 & $\overline{2,546}$ \\
\hline Variance & 4,661 & $\overline{6,484}$ \\
\hline Minimum & $\underline{69}$ & $\underline{62}$ \\
\hline Maximum & $\underline{76}$ & $\underline{70}$ \\
\hline
\end{tabular}

\section{Uji Beda Antara Strategi} TTW dengan Strategi Konvensional Dalam Pembelajaran Membaca Sastra

Uji beda dilakukan dengan tujuan untuk mengetahui perbedaan keefektifan yang terdapat pada penerapan strategi TTW dengan strategi konvensional. Uji beda yang dilakukan menerapkan uji-t sampel bebas dengan ketentuan sebagai berikut: (1) jika skor thitung baik dihitung dengan varian yang sama atau berbeda menghasilkan skor lebih besar dari $t_{\text {tabel }}$ dan taraf signifikasi yang sama-sama signifikan, yaitu kurang dari 0,05, hipotesis kerja diterima, (2) jika skor $t_{\text {hitung }}$ baik dihitung dengan varian yang sama atau berbeda menghasilkan skor lebih kecil dari $t_{\text {tabel }}$ dan menghasilkan taraf signifikasi lebih besar dari 0,05 ,hipotesis kerja ditolak. Berikut ini hasil uji-t terhadap dapat pasca tes kemampuan Menulis Artikel Ilmiah mahasiswa PBSI UMUS semester 6 tahun ajaran 2017/2018.

Hasil uji-t terhadap data pascates kelompok eksperimen dan kelompok kontrol menghasilkan skor $\mathrm{t}$ sebesar
10,114 dan skor signifikasi sebesar 0,000. Berdasarkan hasil tersebut dapat disimpulakan bahwa ada perbedaan yang signifikan terhadap penggunaan strategi TTW dan strategi konvensional dalam pembelajaran menulis artikel ilmiah.

\section{B. Pembahasan}

Menulis artikel ilmiah menjadi suatu tuntutan tertentu bagi para mahasiswa, terutama dalam mengungkapkan gagasan dan ide mereka berdasarkan keilmuan yang dipelajari. Karangan ilmiah atau artikel ilmiah merupakan tulisan yang ilmiah dapat berbentuk artikel ulasan (review articel) maupun artikel penelitian (research articel) dari laporan hasil penelitian yang ditulis kemali oleh para penulisya untuk dipublikasikan dalam jurnal ilmiah (Abdullah dalam Alfiyanti, 2015: 24).

Karangan ilmiah memiliki beberapa karakeristik, yaitu (1) mengacu pada teori, (2) berdasarkan fakta yang ada, (3) logis, (4) Objektif, (5) sistematis, (6) data valid dan jelas, (7) pembahasan yang detail dan tuntas, (8) disusun dalam bahasa yang baku.

Strategi TTW yang diperkenalkan oleh Huinker \& Laughlin ini pada dasarnya dibangun melalui berpikir, berbicara, dan menulis. Strategi TTW adalah sebuah pembelajaran yang dimulai dengan berpikir melalui bahan bacaan (menyimak, mengkritisi, dan solusi alternatif), hasil bacaan dikomunikasikan dengan presentasi, diskusi, kemudian membuat laporan hasil presentasi (Huinker via Yamin, 2009: 84). Strategi TTW mendorong siswa untuk berpikir berbicara, dan kemudian menuliskan suatu topik tertentu (Huda, 2015: 218). Strategi TTW mendorong siswa unuk berpikir, berbicara, dan kemudian menulis. Strategi TTW memperkenankansiswa untuk memengaruhi dan memanipulasi ide-ide sebelum menuangkanya dalam bentuk tulisan. Strategi TTW juga membantu siswa dalam mengumpulkan dan 
mengembangkan ide-ide melalui percakapan struktur.

Melihat skor rata-rata data pascates dari kedua kelas yang digunakan dalam penelitian dapat disimpulkan bahwa terdapat tingkat keefektifan yang berbeda pada kedua strategi tersebut dalam pembelajaran menulis artikel ilmiah. Kelompok penelitian yang menerapkan strategi TTW mendapatkan skor rata-rata yang lebih tinggi dibandingkan dengan kelas kontrol yang menggunakan strategi konvensional dalam pembelajaran menulis artikel ilmiah. Strategi TTW dapat menjadi salah satu alternatif yang dapat digunakan dosen atau guru sebagai strategi dalam pembelajaran menulis artikel ilmiah. Strategi TTW tidak hanya mengharuskan mahasiswa atau peserta didik untuk sekedar menulis, tetapi juga mengharuskan mahasiswa untuk melakukan observasi, pengumpulan data, diskusi dengan kelompok mengevaluasi kinerja lapangan yang selanjutnya dari seluruh rangkaian kegiatan dituangkan dalam bentuk tertulis. Strategi konvensional yang biasa dosen gunakan menempati posisi kedua dalam pembelajaran menulis artikel ilmiah.

\section{SIMPULAN DAN SARAN}

\section{A. Kesimpulan}

Secara keseluruhan hasil perhitungan dan pembahasan, menunjukkan adanya tingkat keefektifan yang berbeda antara kelompok eksperimen dan kelompok kontrol. Memperhatikan hasil uji yang telah dijelaskan sebelumnya, dengan masing-masing skor signifikasi $(\mathrm{p}) \leq$ taraf signifikasi yang telah ditentukan, yakni sebesar 0,05. Jadi dapat disimpulkan bahwa strategi TTW lebih efektif dibandingkan dengan strategi konvensional. Strategi TTW dapat membantu mahasiswa untuk menulis artikel ilmiah dengan melakukan tahapan- tahapan secara runtut dalam strategi TTW.

\section{B. Saran}

Berdasarkan evaluasi yang telah dilakukan dapat diajukan dosen atau pengajar dapat menggunakan strategi TTW, sebagai strategi alternatif dalam pembelajarana menulis artikel ilmiah, sehingga dapat meningkatkan kemampuan menulis peserta didik.

\section{DAFTAR PUSTAKA}

Abidin, Yunus. (2012). Pembelajaran Bahasa Berbasis Pendidikan Karakter. Bandung: Refika Aditama.

Alfiyati, Yati. (2015). Penulisan Artikel Ilmiah. Jakarta: Raja Grafindo Persada.

Badri, Sutrisno. (2012). Metode statistika untuk penelitian kuantitatif. Yogyakarta: Ombak.

Bayat, N. (2014). The effect of the process writing approach on writing success and anxiety [Versi elektronil]. Journal EducationalSciences: Theory \& Practice, 14, 1133-1141.

Brown, H.D. (2001). Teaching by principles an interactive approach to language pedagogy $\left(2^{\text {nd }} e d\right)$. New York: Longman.

Hyland, Ken. (2004). Second language writing. Cambridge: Cambridge University Press.

Huda, Miftahul. 2015. Model-Model pengajaran dan Pembelajaran: Isu-Isu Metodis dan Paradigmatis. Yogyakarta: Pustaka Pelajar.

Kern, Richard. (2014). Literacy and language teaching. New York: Oxford University Press. 
Moore-Hart, Margaret A. (2010).

Teaching writing in diverse classrooms, $\quad k-8$ : Enhancing writing through literature, reallife experiences, and technology. Boston: Pearson Education Inc.

Mourssi, Anwar. (2013). Theoretical and practical linguistic shifting from product/guided writing to process writing and recently to the innovated writing process approach in teaching writing for second/foreign language learners [Versi elektronik]. Journal of Academic Research in Business and Social Sciences, 3, 731-738.

Nunan, David. (2003). Practical english language teaching. New York: Mc Graw-Hill.

Widodo, Handoyo Puji. (2008). Designing a genre-based lesson plan for an academic writing course [Versi elektronik]. Enghlis Teaching Journal, 5, 173-199.

\section{PROFIL SINGKAT}

\footnotetext{
Agnes Apryliana lahir di Banyumas tanggal 10 April 1991. Menyelesaikan studi S1 di Universitas Muhammadiyah dan studi S2 di Universitas Negeri Yogyakarta. Sekarang bekerja sebagai dosen di Universitas Muhadi Setiabudi (UMUS) Brebes.
} 